\title{
Influence of nutrients, temperature, light and salinity on the occurrence of Paralia sulcata at Helgoland Roads, North Sea
}

\author{
Christina Gebühr ${ }^{1, *}$, Karen H. Wiltshire ${ }^{1}$, Nicole Aberle ${ }^{1}$, \\ Justus E. E. van Beusekom ${ }^{2}$, Gunnar Gerdts ${ }^{1}$
}

${ }^{1}$ Biologische Anstalt Helgoland, Alfred Wegener Institute for Polar and Marine Research, POB 180, 27489 Helgoland, Germany ${ }^{2}$ Wadden Sea Station List, Alfred Wegener Institute for Polar and Marine Research, Hafenstraße 43, 25992 List/Sylt, Germany

\begin{abstract}
Paralia sulcata is a tychopelagic centric diatom species common in the North Sea. Due to the fact that $P$. sulcata is found both in the sediment and the water column, it is assumed to be an important food source for both benthic and pelagic grazers. We know a little about the environmental conditions associated with the occurrence of $P$. sulcata, but almost nothing is known of its ecological role. Thus the aim of this study was to investigate the ecology of $P$. sulcata. The Helgoland Roads long-term data set (North Sea), in which phytoplankton and physicochemical parameters have been sampled since 1962, served as the environmental data set. To detect possible species-environment relationships, multivariate statistical analysis was carried out (canonical correspondence analysis). Annual niche breadth and niche position (outlying mean indices) were calculated for P. sulcata. Up to 1996, P. sulcata occurred mainly in late autumn and winter, but since 1997 it has been found throughout the year. The niche position and niche breadth for $P$. sulcata varied over the sampling period. There was a change in the ecological niche of $P$. sulcata, with a shift from a more specialized to a more generalized niche and a new occurrence of this diatom in summer during the last $10 \mathrm{yr}$. Changing temperature, light and nutrient conditions at Helgoland Roads could be responsible for the new occurrence and the shift in the ecological niche of $P$. sulcata.
\end{abstract}

KEY WORDS: Microalgae - Paralia sulcata - Ecological niche $\cdot$ German Bight Nutrients · Temperature $\cdot$ Light $\cdot$ Multivariate statistical analysis

Resale or republication not permitted without written consent of the publisher

\section{INTRODUCTION}

Paralia sulcata (Ehrenberg) Cleve is a centric diatom with robust, chain-forming valves. It benefits from chain formation in terms of protection and increased nutrient and light availability (Crawford 1979). This diatom has a wide distribution and is often found in temperate brackish to marine planktonic and benthic waters, in both littoral and sublittoral zones (McQuoid \& Nordberg 2003a, 2003b). It is often associated with sandy habitats and fine-grained sediments rich in organic material (Roelofs 1984, Zong 1997, McQuoid \& Hobson 1998).

In waters off the southern part of Vancouver Island (British Columbia, Canada), Paralia sulcata was found year-round in cell concentrations of 1500 cells $\mathrm{l}^{-1}$ reaching maximum numbers in winter blooms of 3000 to 6000 cells l$^{-1}$ (Hobson \& McQuoid 1997). As a coldwater alga, $P$. sulcata shows a growth optimum at a temperature of $7 \pm 1{ }^{\circ} \mathrm{C}$ (Hobson \& McQuoid 1997, Zong 1997). P. sulcata displays a competitive advantage under low light conditions (Hobson \& McQuoid 1997) and prefers low temperatures and short day lengths with high irradiance (Roelofs 1984, Zong 1997, McQuoid \& Nordberg 2003b).

Often found in the benthos, the presence of Paralia sulcata in the phytoplankton could be dependent on vertical transport processes and resuspension into the plankton by strong winds and tidal mixing (Roelofs 1984, Hobson \& McQuoid 1997). Increased vertical mixing in the water column brings nutrient-rich, saline water to the 
surface, thus creating conditions which favour the occurrence of P. sulcata (McQuoid \& Nordberg 2003b). Abrantes (1988) showed that $P$. sulcata is correlated with higher nutrient concentrations and is typically found in regions with high levels of upwelling. The higher nutrient concentrations due to remineralisation processes in coastal waters and storm activity in winter could explain the occurrence of P. sulcata in the water column. Furthermore, salinity may have an impact on the abundance of $P$. sulcata, which has been shown to be negatively correlated with low salinity in British Columbia inlets (Roelofs 1984). Elsewhere, Zong (1997) has shown that $P$. sulcata has a wide salinity tolerance range (5 to $>30$ ).

We know a little about the environmental conditions associated with the occurrence of Paralia sulcata but we know almost nothing of its ecological role. Due to its thick siliceous valves, this diatom is often found in late Quaternary sediments (Zong 1997). As diatoms have existed since the early Mesozoic (Medlin et al. 1997), they can serve as good palaeoindicators of past changes in coastal regions due to their abundance in sediments and can act as proxies for specific environmental conditions (McQuoid \& Nordberg 2003a). An understanding of the ecology of $P$. sulcata would therefore be helpful for the reconstruction of past environmental conditions.

To determine the ecological niche of Paralia sulcata, an analysis of the response of this species to several environmental parameters is needed. According to the ecological niche concept, each species has its own environmental optimum, and the fundamental niche is defined as a multidimensional space where the environmental conditions could limit the growth of a species (Hutchinson 1957, Begon et al. 1996). According to Kearney (2006), a realized niche is defined as the sum of all abiotic and biotic factors which influence the organism's growth and fitness and the interactions between the organism and environmental parameters; the realized niche should be smaller than the fundamental niche (McGill et al. 2006). In order to define optimum conditions for habitats or ecological niches of species with statistical models, it is essential to determine particular niche parameters, i.e. niche breadth and niche position, from the field data.

There are numerous statistical methods for analysing ecological niches. For the present study, canonical correspondence analysis (CCA) and outlying mean index (OMI) analysis were selected to describe the ecological niche of Paralia sulcata. CCA extracts environmental gradients from ecological data sets, which are the basis for describing the habitat preference of a species (ter Braak \& Verdonschot 1995, Dolédec et al. 2000). A newly developed approach, OMI determines the niche breadth and niche position of a given species (Dolédec et al. 2000).
Since 1962, a daily monitoring program has been maintained at Helgoland Roads which has resulted in one of the most important marine data sets in the world, unique with respect to the length of the timeseries, sampling frequency and number of parameters measured (Franke et al. 2004, Wiltshire \& Manly 2004). These long-term data have been used for modelling ecosystem functions (Wirtz \& Wiltshire 2005) as well for investigations into ecological questions concerning bacteria (Gerdts et al. 2004), phytoplankton (Wiltshire \& Dürselen 2004, Wiltshire \& Manly 2004, Wiltshire et al. 2008, in press), zooplankton (Greve et al. 2004), macroalgae communities (Bartsch \& Tittley 2004) and macrozoobenthos (Franke \& Gutow 2004).

From the phytoplankton data set we know that the abundance of Paralia sulcata has been changing over the last 40 yr at Helgoland Roads (Wiltshire \& Dürselen 2004 ), yet the food quality of this diatom in the marine food web in the North Sea is unknown. It is possible that $P$. sulcata has become a more important food source for benthic and pelagic grazers due to its increasing abundance in the summer but this requires more detailed investigation.

Here we investigate the influence of nutrients, light, temperature and salinity on the occurrence of Paralia sulcata using the long-term data series from Helgoland Roads. We determine the ecological niche of this diatom and how it has adapted to changing environmental conditions. This information will enable a description of the temporal changes of P. sulcata at Helgoland Roads, identification of the determining factors of its occurrence and the variability in niche position and breadth of $P$. sulcata over time.

\section{MATERIALS AND METHODS}

Study site. Helgoland is situated in the German Bight about $60 \mathrm{~km}$ from the mainland and the estuaries of the rivers Elbe and Weser $\left(54^{\circ} 11.3^{\prime} \mathrm{N}, 7^{\circ} 54.0^{\prime} \mathrm{E}\right)$. The German Bight is a transition zone between the well-mixed low saline coastal waters and the deeper waters of the southeastern North Sea (Bauerfeind et al. 1990). Dependent on the meteorological situation, the water around Helgoland is influenced by the lower coastal saline waters or the open North Sea several times in the year due to currents and tidal mixing (Hickel 1998, Wiltshire et al. in press). The water depth at Helgoland Roads fluctuates between 3 and $8 \mathrm{~m}$ over the tidal cycle.

Sampling and data sets. A series of periodic measurements and daily water sampling was initiated by the Biologische Anstalt Helgoland at Helgoland Roads in 1962 (Franke et al. 2004) (54 $11.3^{\prime}$ N, $7^{\circ} 54.0^{\prime}$ E). Surface water samples represented the entire water col- 
umn, which is generally well-mixed as a result of strong tidal currents (Hickel 1998). The surface water samples were taken from the RV 'Aade' with a bucket. Identification and enumeration of the phytoplankton and analyses of physicochemical parameters like salinity, temperature, Secchi depth and dissolved inorganic nutrients (ammonium, nitrate, nitrite, phosphate and silicate) were measured and analysed daily (Wiltshire \& Manly 2004, Wiltshire et al. in press). For quantitative measurement of phytoplankton, the water sample was well mixed, subsampled into a brown glass bottle and fixed with Lugol's iodine solution. Daily counting of the phytoplankton was conducted according to the method of Lund et al. (1958) in 25 or $50 \mathrm{ml}$ Utermöhl settling chambers with an inverted microscope (Axiovert 135, Zeiss); phytoplankton were identified to species level or separated into size classes by microscopically measuring species size (Wiltshire \& Dürselen 2004).

A subsample from the water sample was used to measure the salinity with a Salinometer (Autosal, Gamma Analysen Technik) and for the colorimetric determination of the nutrients after Grasshoff (1976). All data has been reviewed and quality controlled by Raabe \& Wiltshire (2009). Radiation data (global net shortwave radiation from 100 to $700 \mu \mathrm{m}$ ) was provided by the GKSS Research Centre (Geesthacht, Germany).

The explanatory variables included in the multivariate analysis are temperature, the temperature difference between 2 consecutive weeks, Secchi depth, salinity, solar radiation and concentrations of ammonium, nitrate, nitrite, phosphate and silicate (Table 1).

The algal data set used in the multivariate statistical analysis is a subset from the Helgoland Roads algal data. It was composed of 3 species from the class Dinophyceae (Ceratium furca, C. fusus and C. horridum) and 15 from Bacillariophyceae (Eucampia zodiacus, Guinardia delicatula, G. striata, Melosira spp., Navicula spp., Odontella aurita, O. mobiliensis, O. regia, O. rhombus, O. sinensis, Paralia sulcata, Skeletonema costatum, Thalassionema nitzschioides, Thalassiosira nordenskioeldii and Thalassiosira rotula) (Table 1). Some taxa have not been continuously identified to species level (Hoppenrath 2004, Wiltshire \& Dürselen 2004), such as Melosira spp. and Navicula spp., here determined to genus. All algae chosen for analyses regularly occur in the water column at Helgoland Roads and virtually complete records exist from 1962 to the present day (Wiltshire \& Dürselen 2004). The phytoplankton data have been quality controlled by Wiltshire \& Dürselen (2004). The Bacillariophyceae were used because of their chain-forming properties and centric morphology (as with Paralia). Navicula spp. and Thalassionema nitzschioides were the only pennate exceptions, occurring continuously since 1962
Table 1. Explanation and abbreviations of the response variables (algae) and environmental parameters used for the statistical analysis of the algal community at Helgoland Roads, North Sea

\begin{tabular}{|c|c|}
\hline Term & Abbreviation \\
\hline \multicolumn{2}{|l|}{ Response variable (algae) } \\
\hline Ceratium furca & C.fur \\
\hline Ceratium fusus & C.fus \\
\hline Ceratium horridum & C.hor \\
\hline Eucampia zodiacus & E.zod \\
\hline Guinardia delicatula & G.del \\
\hline Guinardia striata & G.str \\
\hline Melosira spp. & Mel.spec \\
\hline Navicula spp. & Nav.spec \\
\hline Odontella aurita & O.aur \\
\hline Odontella mobiliensis & O.mob \\
\hline Odontella regia & O.reg \\
\hline Odontella rhombus & O.rho \\
\hline Odontella sinensis & O.sin \\
\hline Paralia sulcata & P.sul \\
\hline Skeletonema costatum & S.cos \\
\hline Thalassionema nitzschioides & T.nit \\
\hline Thalassiosira nordenskioeldii & T.nor \\
\hline Thalassiosira rotula & T.rot \\
\hline \multicolumn{2}{|l|}{ Environmental parameter } \\
\hline Global solar radiation $\left(\mathrm{W} \mathrm{m}^{-2}\right)$ & Rad \\
\hline Secchi depth $(\mathrm{m})$ & Secchi \\
\hline Temperature $\left({ }^{\circ} \mathrm{C}\right)$ & Temp \\
\hline Salinity & Sal \\
\hline Phosphate $\left(\mu \mathrm{mol} \mathrm{l}^{-1}\right)$ & $\mathrm{PO}_{4}$ \\
\hline Nitrite $\left(\mu \mathrm{mol} \mathrm{l} \mathrm{l}^{-1}\right)$ & $\mathrm{NO}_{2}$ \\
\hline Nitrate $\left(\mu \mathrm{mol} \mathrm{l}^{-1}\right)$ & $\mathrm{NO}_{3}$ \\
\hline Ammonium $\left(\mu \mathrm{mol} \mathrm{l} \mathrm{l}^{-1}\right)$ & $\mathrm{NH}_{4}$ \\
\hline Silicate $\left(\mu \mathrm{mol} \mathrm{l}^{-1}\right)$ & $\mathrm{SiO}_{4}$ \\
\hline
\end{tabular}

at Helgoland and used here as the counterpart to the centric diatoms. The Dinophyceae were selected because they are representative of summer season algae and there are unbroken records for their occurrence (Wiltshire \& Dürselen 2004).

Statistical analysis. Only data from 1968 to 2005 were used for statistical analysis due to the high number of missing data points at the beginning of the monitoring program (e.g. determination of silicate started in 1966 and Secchi depth measurements began in 1968). The weekly mean was calculated for all data. A total of 90 missing weeks were interpolated linearly.

The multivariate statistical analysis of such longterm data is not easy to interpret because these results cannot be verified or refuted by experiments in the laboratory. Statistical analysis is not an analysis of cause or effect, but this multivariate analysis is helpful for describing ecological interactions which could be investigated in experiments on a smaller scale.

Influence of environmental factors: Multivariate ordination techniques were applied to determine the significant environmental factors affecting Paralia sul- 
cata and for the investigation of seasonal trends. To estimate whether weighted-averaging or linear techniques should be applied, for each selected data subset (individual years) a detrended correspondence analysis (DCA) was performed using CANOCO for Windows 4.53 (Biometris). The gradient of the first DCA axis describes the extent of the species turnover along the major ecological factors (e.g. the diversity of the community composition along the environmental gradients) and gradients with lengths of more than $4 \mathrm{SD}$ represent a complete species turnover indicating a unimodal ordination technique (Leps \& Smilauer 2003, Heino \& Soininen 2005). SD values between 3 and 4 did not indicate a clear linear or unimodal relationship (Leps \& Smilauer 2003). Thus the selection of redundancy analysis (RDA) or CCA requires the selection of a linear or unimodal model for the species response to the environmental parameters (Dolédec et al. 2000). Hence, RDA as well as CCA were performed to examine species-environment correlations and to test for the significance of the resulting eigenvalues and species-environment correlations.

RDA and CCA were carried out as described by Leps $\&$ Smilauer (2003). The marginal and conditional effects quantify the effects of the environmental parameters on the response variables and were selected according to their ranking or significance level ( $\mathrm{p}<$ 0.05) as determined by Monte Carlo permutation (499 permutations). Marginal effects represent the influence of each environmental parameter on the algal community. Higher values indicate a greater influence on the algal community. Conditional effects demonstrate the combined effects of environmental variables on the algal community (Leps \& Smilauer 2003). Bi-plot scaling was used for the community ordination analysis (Leps \& Smilauer 2003). An overall CCA for the total time period (1968 to 2005) was performed to determine the general pattern of environmental parameters and algal community. An automated forward selection with a restricted permutation test for temporal structure of the time-series was used with 499 permutations.

To support the results of the CCA and to show correlations between Paralia sulcata and environmental parameters, the non-parametric Spearman rank correlation was calculated using STATISTICA 7.1 (StatSoft) with a significance level of $\mathrm{p}<0.05$.

Ecological niche: The OMI of Paralia sulcata was calculated using $\mathrm{R}$ version 2.6.0. and the software package ADE-4 (R Development Core Team 2007). This multivariate technique quantifies the niche parameters with consideration of niche position and niche breadth for the diatom along several environmental gradients (Dolédec et al. 2000, Lappalainen \& Soininen 2006). In this analysis, the realized niche was calculated using the measured and sampled field data.
Niche position is a measure of the distance of average habitat conditions (the measured environmental parameters) used by this species from the average habitat conditions of the sampling site. Species tolerance represents the niche breadth of this species associated with the environmental parameters (Dolédec et al. 2000). If the values of species tolerance are lower, the species is considered a specialist. In contrast, generalists are assumed to live in a habitat with widely varying environmental conditions and thus they show higher values of species tolerance (Dolédec et al. 2000, Heino \& Soininen 2006, Tsiftsis et al. 2008).

To determine similarities between different years from the given environmental parameters an analysis of similarities (ANOSIM) was performed using PRIMER software (version 6.1.6, PRIMER-E). ANOSIM is a nonparametric method which allows statistical comparisons for multivariate data in a similar way to univariate techniques (Clarke \& Warwick 2001). All environmental parameters for the years 1968 to 2005 were normalised before analysis and the Euclidean distance was calculated. Hierarchical cluster analysis (pairwise tests, group averages) was carried out on the basis of ANOSIM rho-values. The result of the hierarchical cluster analysis is the differentiation of 4 groups of year clusters based on the environmental parameters.

Niche position and niche breadth of Paralia sulcata were correlated with the most important environmental parameters, as extracted from the CCA, to test for the effects of these parameters on niche position and niche breadth. The Spearman rank correlation and product-moment correlation were calculated with annual mean environmental parameters and their standard deviation for niche position and niche breadth for the 4 different clustered year groups.

\section{RESULTS}

Fig. 1 gives a data plot of the important environmental parameters influencing the occurrence of Paralia sulcata at Helgoland Roads and shows significant changes in temperature, Secchi depth and phosphate concentrations from 1968 to 2005. From 1968 to 1996, Paralia sulcata occurred at Helgoland Roads exclusively in autumn, winter and early spring with a mean abundance of around 3000 cells l$^{-1}$ (Fig. 2). Since 1997, this diatom has also been detected during summer in the water column at around 1000 cells $1^{-1}$. There is a high intra- and inter-annual variability in the abundances of $P$. sulcata. This may be due to the overall patchiness in the water column at Helgoland Roads and upwelling processes in the North Sea, as well as strong tidal mixing and storm-induced mixing in autumn and winter. 

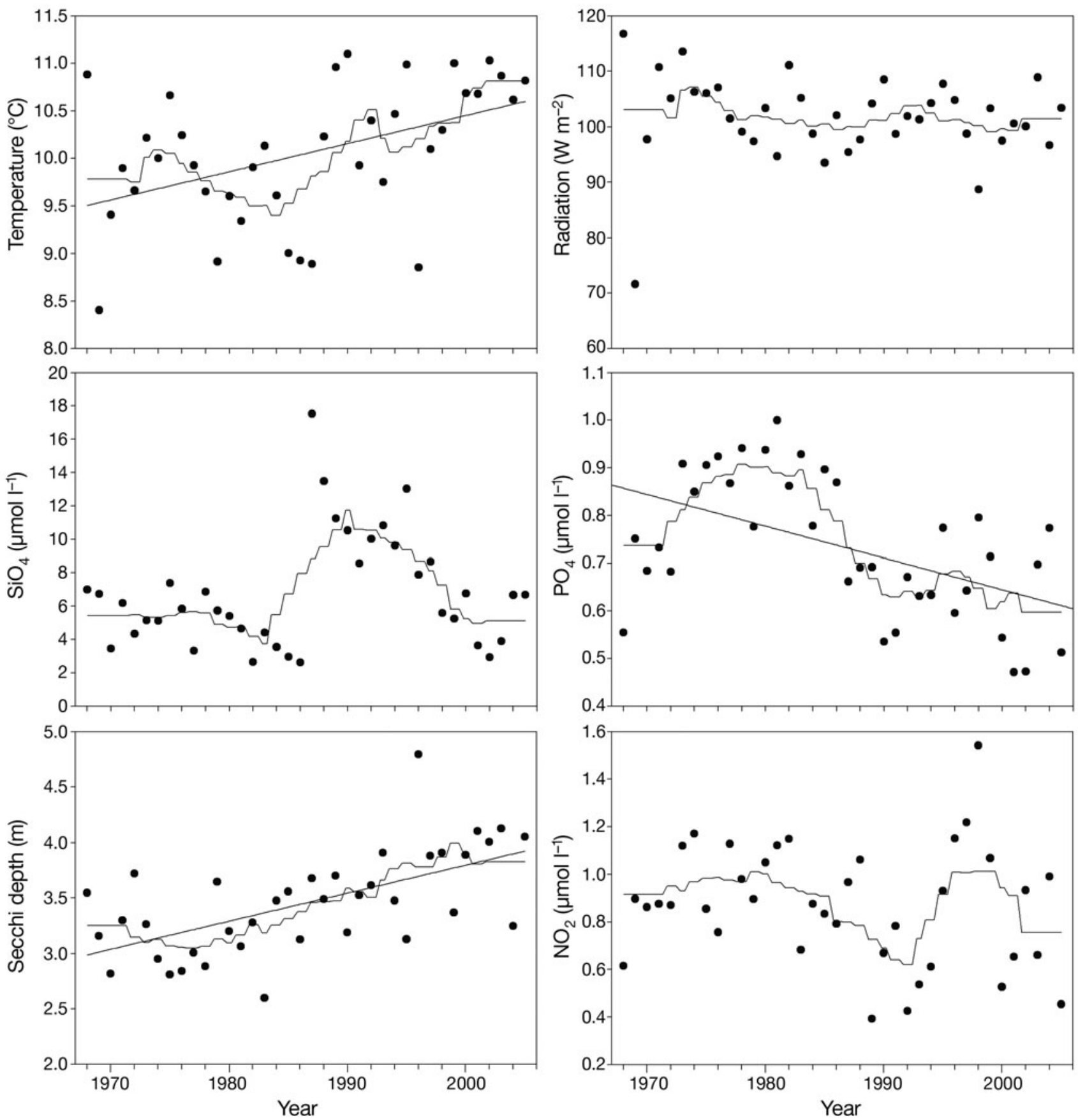

Fig. 1. Time-series plots of the annual mean of the environmental parameters measured at Helgoland Roads. Running means indicate the trend of these parameters. Significant changes are shown for temperature $\left(R^{2}=0.2055, p<0.05\right)$, Secchi depth $\left(\mathrm{R}^{2}=0.3732, \mathrm{p}<0.05\right)$ and phosphate $\left(\mathrm{R}^{2}=0.2566, \mathrm{p}<0.05\right)$

\section{Influence of environmental factors on Paralia sulcata}

The results of the DCA showed that the length of gradients varied from 2.63 to 6.77 , so CCA or RDA was subsequently performed (Table 2). A high variability in the algal community and the species-environment correlation was observed, which is explained by the first axis of the CCA and RDA.
A CCA covering all years from 1968 to 2005 was carried out for the impact of environmental parameters on the algal community. The position of the algal species on the first 2 canonical axes gave a qualitative indication of their environmental optima (Fig. 3). The algal community is influenced by 6 major parameters: water temperature, Secchi depth, global solar radiation and phosphate, nitrite and silicate concentrations extracted 


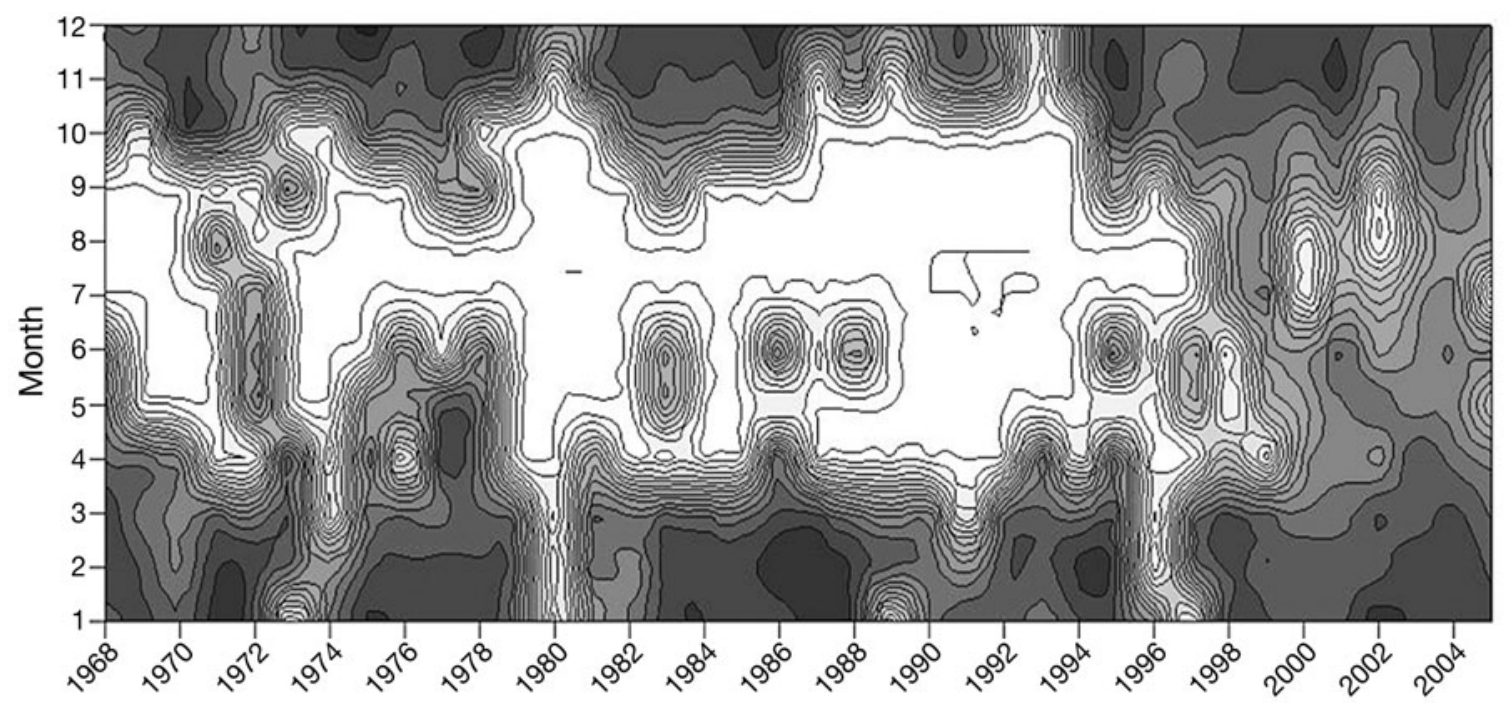

Fig. 2. Paralia sulcata. Log-transformed abundance from 1968 to 2005

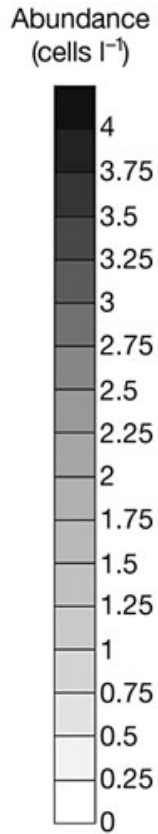

Table 2. Length of gradients, variability of algae community and species-environment correlations of the first axis of the canonical correspondence (CCA) and redundancy analyses (RDA). Significant axes are labelled with an asterisk (p < 0.05)

\begin{tabular}{|c|c|c|c|c|c|c|c|c|c|}
\hline Year & $\begin{array}{l}\text { Gradient } \\
\text { length }\end{array}$ & CCA/RDA & $\begin{array}{l}\text { Variability } \\
\text { of algae } \\
\text { community }\end{array}$ & $\begin{array}{l}\text { Species- } \\
\text { environment } \\
\text { correlation }\end{array}$ & Year & $\begin{array}{l}\text { Gradient } \\
\text { length }\end{array}$ & CCA/RDA & $\begin{array}{l}\text { Variability } \\
\text { of algae } \\
\text { community }\end{array}$ & $\begin{array}{c}\text { Species- } \\
\text { environment } \\
\text { correlation }\end{array}$ \\
\hline 1968 & 3.419 & $\mathrm{CCA}$ & 17.5 & $0.876^{*}$ & 1988 & 5.209 & $\mathrm{CCA}$ & 26.0 & $0.982^{*}$ \\
\hline 1969 & 4.945 & $\mathrm{CCA}$ & 49.5 & $0.962^{*}$ & 1989 & 4.913 & $\mathrm{CCA}$ & 27.0 & $0.996^{*}$ \\
\hline 1970 & 4.201 & $\mathrm{CCA}$ & 22.0 & $0.963^{*}$ & 1990 & 4.027 & $\mathrm{CCA}$ & 29.0 & $0.957^{*}$ \\
\hline 1971 & 4.235 & CCA & 21.6 & $0.988^{*}$ & 1991 & 4.411 & $\mathrm{CCA}$ & 20.4 & $0.977^{*}$ \\
\hline 1972 & 4.13 & $\mathrm{CCA}$ & 18.5 & $0.980^{*}$ & 1992 & 5.913 & $\mathrm{CCA}$ & 24.2 & $0.983^{*}$ \\
\hline 1973 & 3.416 & CCA & 24.0 & $0.964^{*}$ & 1993 & 3.775 & $\mathrm{CCA}$ & 34.5 & $0.996^{*}$ \\
\hline 1974 & 4.611 & CCA & 22.0 & $0.983^{*}$ & 1994 & 3.051 & RDA & 25.9 & 0.540 \\
\hline 1975 & 3.788 & CCA & 27.0 & $0.961^{*}$ & 1995 & 3.793 & CCA & 30.7 & $0.940^{*}$ \\
\hline 1976 & 4.012 & CCA & 23.8 & $0.938^{*}$ & 1996 & 3.149 & RDA & 38.3 & $0.621^{*}$ \\
\hline 1977 & 4.882 & CCA & 23.6 & $0.953^{*}$ & 1997 & 4.022 & CCA & 29.7 & $0.985^{*}$ \\
\hline 1978 & 3.758 & CCA & 26.6 & $0.941^{*}$ & 1998 & 3.052 & RDA & 25.3 & 0.547 \\
\hline 1979 & 4.207 & $\mathrm{CCA}$ & 26.4 & $0.977^{*}$ & 1999 & 2.825 & RDA & 19.8 & 0.450 \\
\hline 1980 & 0 & RDA & 36.4 & $0.842^{*}$ & 2000 & 2.814 & RDA & 38.9 & $0.674^{*}$ \\
\hline 1981 & 4.65 & CCA & 23.1 & $0.918^{*}$ & 2001 & 2.63 & RDA & 23.3 & 0.489 \\
\hline 1982 & 3.368 & RDA & 21.6 & $0.707^{*}$ & 2002 & 3.69 & CCA & 26.8 & $0.922^{*}$ \\
\hline 1983 & 3.946 & CCA & 20.5 & $0.830^{*}$ & 2003 & 2.91 & RDA & 26.3 & 0.615 \\
\hline 1984 & 6.768 & CCA & 19.2 & $0.943^{*}$ & 2004 & 3.121 & RDA & 22.8 & 0.516 \\
\hline 1985 & 4.278 & CCA & 25.9 & $0.968^{*}$ & 2005 & 4.162 & $\mathrm{CCA}$ & 16.3 & $0.928^{*}$ \\
\hline 1986 & 3.829 & $\mathrm{CCA}$ & 34.4 & $0.992^{*}$ & $1968-2005$ & 4.581 & $\mathrm{CCA}$ & 5.8 & $0.697^{*}$ \\
\hline 1987 & 5.336 & CCA & 19.5 & $0.969^{*}$ & $1900-2000$ & 4.001 & $C A$ & 0.0 & 0.097 \\
\hline
\end{tabular}

from the conditional effects (Table A1 in Appendix 1). High water temperatures, Secchi depth and radiation are positively correlated, as are silicate, phosphate, nitrite and nitrate concentrations. It was shown that light, Secchi depth and temperature were mostly negatively correlated with nutrients. This pattern reflects the typical conditions found for different seasons, where spring to summer (April to September) is characterized by higher light levels and warmer water temperature and autumn to winter (October to March) by higher nutrient concentrations. This reflects a common pattern for temperate regions where, for example, the winter period is characterized by lower water temperatures and light conditions but higher concentrations of nutrients due to recycling processes in the water column like we observed at Helgoland Roads. In late spring and summer, the concentrations of nutrients are much lower, limiting the algal growth. The monthly pairwise test of the ANOSIM with all environmental parameters showed the same pattern for the seasons (data not shown). 


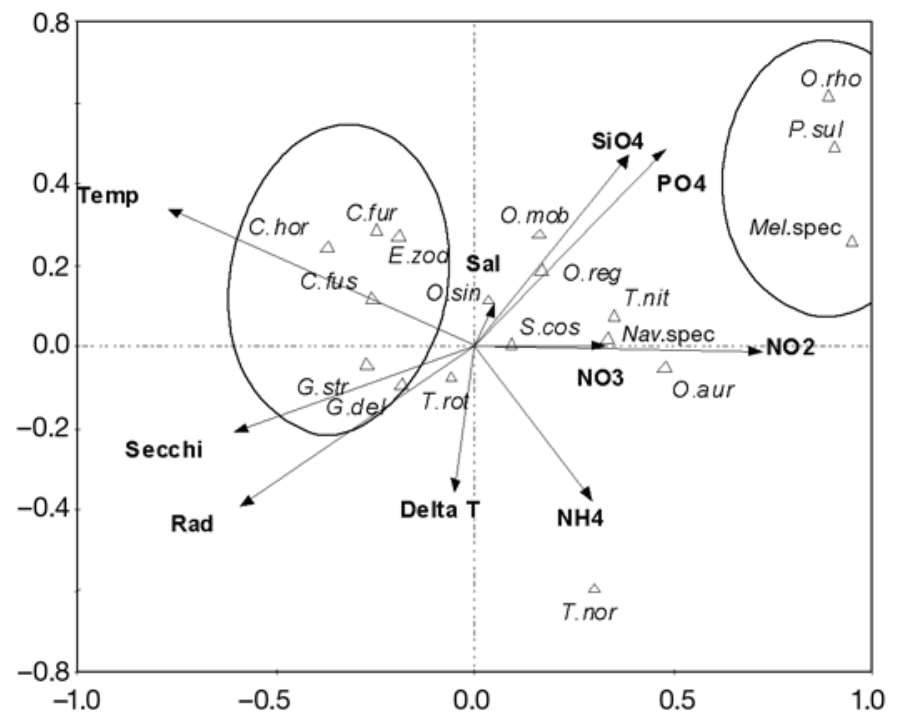

Fig. 3. Biplot diagram showing the 1st (horizontal) and 2nd (vertical) canonical correspondence analysis (CCA) axes of inter-species distance from 1968 to 2005 of phytoplankton composition and environmental parameters at Helgoland Roads, North Sea. Length and direction of environmental parameter arrows indicate their importance (in terms of the influence on) the phytoplankton community. Algae data are shown as triangles, using the calculated weighted averaging method, indicating the species optima in the environment. Algae grouped together are mostly pooled together in the CCA, and indicate seasonal assemblages (winter: Paralia sulcata, Odontella rhombus and Melosira spp.; summer: Ceratium spp., Guinardia spp. and Eucampia zodiacus). Abbreviations of algae and environmental parameters in Table 1 man rank correlation for $P$. sulcata was negative with radiation $(\mathrm{R}=-0.658, \mathrm{p}<0.05)$, Secchi depth $(\mathrm{R}=$ $-0.587, \mathrm{p}<0.05)$ and temperature $(\mathrm{R}=-0.411, \mathrm{p}<0.05)$ and positive with phosphate $(\mathrm{R}=0.483, \mathrm{p}<0.05)$, nitrite $(R=0.411, p<0.05)$, silicate $(R=0.303, p<0.05)$ and salinity $(\mathrm{R}=0.281, \mathrm{p}<0.05)$. The occurrence of $P$. sulcata blooms in winter is reflected by these correlations, as this alga shows an adaptation to low light conditions and low water temperatures. A positive relationship between the occurrence of $P$. sulcata and the silicate concentrations in the water column was found, which might fuel the high silicate demand of $P$. sulcata. Silicate is a nutrient of pivotal importance as it is required for the production of $P$. sulcata's strongly silicified valves.

Summarizing the results shown by the CCA, the most important environmental parameters influencing Paralia sulcata abundance were temperature, light conditions and phosphate and silicate concentrations.

\section{Ecological niche of Paralia sulcata}

With the exception of 1980 (where Paralia sulcata appeared only once), the yearly niche position and niche breadth was calculated for all years of the time series. The niche position and niche breadth of $P$. sulcata showed large interannual differences from 1968 to 2005 and could be grouped into 4 clusters (Fig. 4). At the beginning of time period (1968 to 1978), niche posi-
This CCA showed a typical pattern for the algae species. Along with Paralia sulcata, a group of algae was associated with comparable environmental conditions such as very low light and Secchi depth, low water temperature and high nutrient concentrations, which is representative of winter and early spring conditions (Fig. 3). This group consisted of Melosira spp., Odontella rhombus, O. aurita, O. mobiliensis, O. regia and Thalassionema nitzschioides. Another species group, Ceratium furca, C. fusus, C. horridum, Eucampia zodiacus, Guinardia delicatula, G. striata and Odontella sinensis, was mostly abundant at warmer water temperatures, high light conditions and higher Secchi depth, indicating typical summer conditions. The growth of Ceratium spp. was mostly independent of silicate concentrations, and negatively correlated to nutrients, reflecting typical summer conditions.

To show the correlation of Paralia sulcata with the environmental parameters, the Spearman rank correlation coefficient was calculated for the entire time period (1968 to 2005). The Spear-

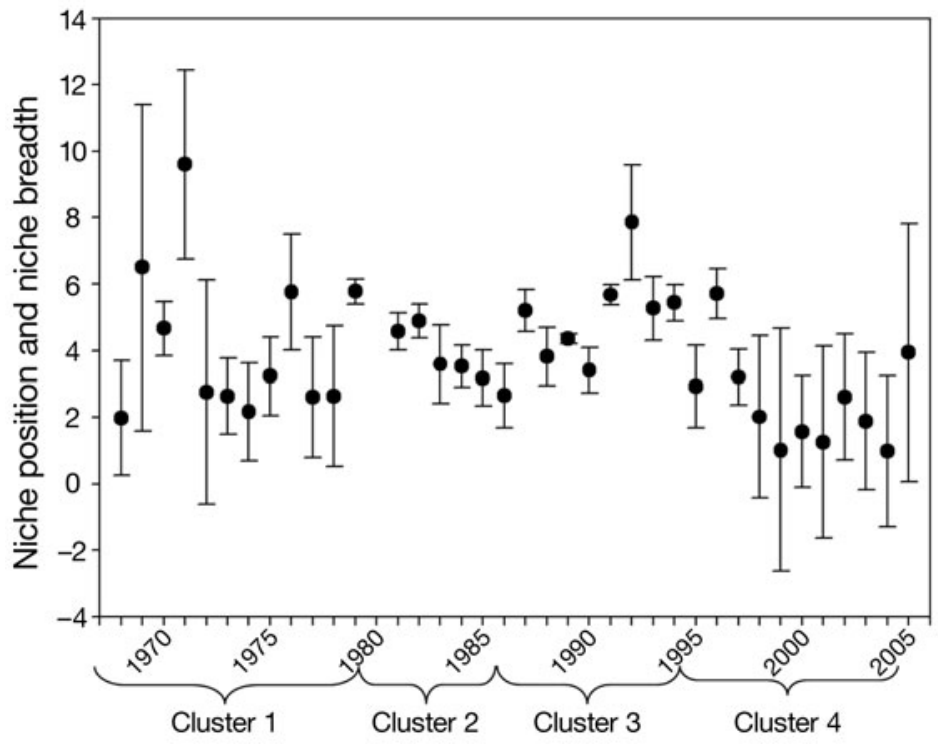

Fig. 4. Paralia sulcata. Niche position (filled circle) and niche breadth (species tolerance, bars) from 1968 to 2005. The years which are grouped together are the same clusters as those found in the ANOSIM cluster analysis of the environmental parameters for the years 1968 to 2005 (see Fig. 5) 
tion fluctuated, while niche breadth did not change a great deal. From 1979 to 1986, niche position decreased continuously, indicating a switch from a specialized to a more generalized niche position. The narrow niche breadth indicated a specialized niche for $P$. sulcata. In the following years until 1995, niche position fluctuated and the narrow niche breadth again indicated a more specialized ecological niche for $P$. sulcata. From 1996 to 2005, niche position decreased and niche breadth became wide, reflecting a more generalized ecological niche of P. sulcata (Fig. 4).

Interestingly, the similar years which grouped together in the ANOSIM cluster analysis presented the same year cluster in niche position and niche breadth of Paralia sulcata (Figs. 4 \& 5). Based on the ANOSIM analysis, similar environmental conditions were found for Cluster 1

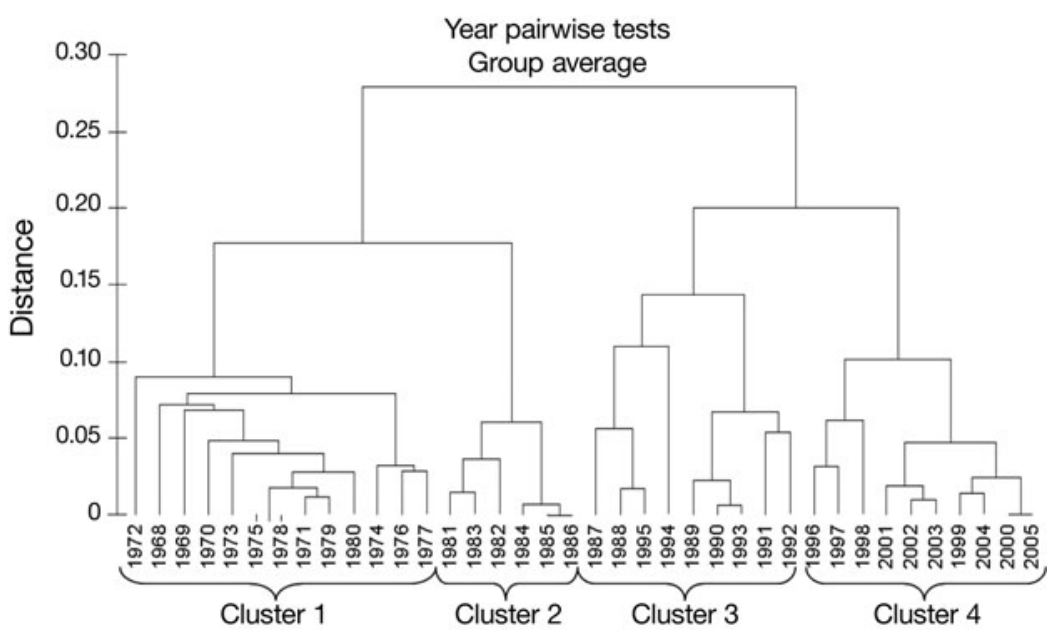

Fig. 5. Dendrogram of the ANOSIM cluster analysis of environmental parameters for the years 1968 to 2005. Four clusters are shown; years in each cluster indicate similar environmental conditions from 1968 to 1980, Cluster 2 from 1981 to 1986, Cluster 3 from 1987 to 1995 and Cluster 4 from 1996 to 2005. Only the transition years such as 1978 to 1981 showed a bigger change in niche position and niche breadth. A clear change in niche position of $P$. sulcata was found from 1986 to 1987 , indicating the transition between Clusters 2 and 3. The niche breadths of Clusters 2 and 3 were significantly smaller than those of Clusters 1 and 4 (ANOVA, LSD-test, $\mathrm{p}<0.05$ ).

The Spearman rank correlation and product-moment correlation coefficients were also calculated for niche position and niche breadth of Paralia sulcata with the annual mean environmental parameters and their standard deviations (Table 3). Cluster 1 is influenced by the negative correlation for niche breadth of $P$. sulcata with standard deviations of temperature and salinity explaining 33 and $38 \%$ of the interannual variability, respectively. Cluster 2 clearly shows a smaller niche breadth of $P$. sulcata indicating a specialized niche. The main factors influencing the ecological niche are nitrite concentrations and salinity. Cluster 2 is affected by the standard deviation of salinity, which explains $87 \%$ of the variability in niche position, and the annual mean of nitrite, which explains $70 \%$ of the variability in niche position and $84 \%$ of the variability in niche breadth. The last cluster (1996 to 2005) exhibits a clear generalized ecological niche of $P$. sulcata. Cluster 4 is influenced by annual mean temperature, explaining $55 \%$ (niche position) and $43 \%$ (niche breadth) of the variability, and Secchi depth, explaining $62 \%$ of the variability

Table 3. Spearman rank and product-moment correlation coefficients for the environmental parameters and their standard deviation and niche parameters of Paralia sulcata in the 4 clusters (significance level, $\mathrm{p}<0.05$ ). Abbreviations as in Table 1. Means are annual means of environmental parameters

\begin{tabular}{|c|c|c|c|c|c|}
\hline $\begin{array}{l}\text { Environmental } \\
\text { parameter }\end{array}$ & Niche parameter & $\begin{array}{l}\text { Spearman rank } \\
\text { correlation }\end{array}$ & $\begin{array}{l}\text { Environmental } \\
\text { parameter }\end{array}$ & Niche parameter & $\begin{array}{l}\text { Product-moment } \\
\text { correlation }\end{array}$ \\
\hline \multicolumn{3}{|l|}{ Cluster 1} & \multicolumn{3}{|l|}{ Cluster 1} \\
\hline Temp SD & Niche breadth & -0.587 & Sal SD & Niche breadth & -0.616 \\
\hline Sal SD & Niche breadth & -0.643 & \multicolumn{3}{|l|}{ Cluster 2} \\
\hline \multicolumn{3}{|l|}{ Cluster 2} & $\mathrm{NO}_{2}$ mean & Niche position & 0.839 \\
\hline $\mathrm{NH}_{4} \mathrm{SD}$ & Niche breadth & 0.886 & $\mathrm{NO}_{2}$ mean & Niche breadth & -0.917 \\
\hline Sal SD & Niche position & 0.943 & $\mathrm{NO}_{2} \mathrm{SD}$ & Niche position & 0.990 \\
\hline Sal SD & Niche breadth & -0.829 & Sal SD & Niche position & 0.934 \\
\hline \multirow{6}{*}{$\begin{array}{l}\text { Cluster } 4 \\
\text { Secchi SD }\end{array}$} & & & Sal SD & Niche breadth & -0.860 \\
\hline & Niche position & 0.661 & \multicolumn{3}{|l|}{ Cluster 4} \\
\hline & & & Temp mean & Niche position & -0.742 \\
\hline & & & Temp mean & Niche breadth & 0.654 \\
\hline & & & Temp SD & Niche position & 0.645 \\
\hline & & & Secchi mean & Niche position & 0.787 \\
\hline
\end{tabular}


in niche position (Table 3). There is a clear trend of $P$. sulcata switching to a more specialized niche position with increasing Secchi depth. The correlations of niche position and niche breadth with annual mean temperature are interesting, indicating a clear trend from a specialized to a generalized niche with increasing temperature.

The results of the Spearman rank correlation analysis of niche position and niche breadth showed that only the niche position of Paralia sulcata was highly negatively correlated with temperature $(\mathrm{R}=-0.493$, $\mathrm{p}=0.002)$, whereas the other parameters showed no significant influence on niche position or niche breadth. This indicates a strong influence of temperature on $P$. sulcata; increasing temperatures in the North Sea could have led to a change in niche position to a more generalized niche. But no environmental factor alone is responsible for the shift in the ecological niche of $P$. sulcata; therefore, other parameters such as Secchi depth, nitrite and salinity could have also influenced this shift, albeit to a lesser degree.

\section{DISCUSSION}

\section{Influence of environmental parameters on Paralia sulcata}

At Helgoland Roads, high abundances of Paralia sulcata do not occur relative to the total diatom counts, due to the fact that $P$. sulcata does not form typical blooms (Roelofs 1984). The occurrence of P. sulcata at Helgoland Roads has changed over the last 40 yr (Wiltshire \& Dürselen 2004, Wiltshire et al. in press). Up to 1996, $P$. sulcata occurred only in autumn and winter; however, since 1997 this diatom has been abundant year-round. Changing environmental conditions at Helgoland Roads could be an explanation for the new occurrence in summer.

The CCA extracted a typical seasonal pattern for Paralia sulcata, which occurs mostly in winter with low light and temperature conditions and higher nutrient concentrations, but does not show a shift in the ecological niche of $P$. sulcata. $P$. sulcata abundance is positively influenced by higher silicate, phosphate and nitrite concentrations and negatively influenced by higher light and temperature conditions.

A negative correlation of the abundance of Paralia sulcata and temperature was described by Hobson \& McQuoid (1997). Although temperatures in the southern part of Vancouver Island were slightly higher in winter (mean of $8.1^{\circ} \mathrm{C}$ ) and cooler in summer (mean of $13.7^{\circ} \mathrm{C}$ ) (Hobson \& McQuoid 1997), the abundance pattern of $P$. sulcata shows similar seasonal patterns to those found at Helgoland Roads. Another study has shown that temperature has positive effects on the abundance of $P$. sulcata in the water column in British Columbia inlets (Roelofs 1984, Zong 1997). In the present study, we detected a clearly negative correlation between temperature and P. sulcata. The new occurrence of $P$. sulcata in the last $15 \mathrm{yr}$ in summer could be explained by the adaptation of $P$. sulcata to a recent warming trend of the North Sea of 1.13 to $1.33^{\circ} \mathrm{C}$ over the last 40 to $50 \mathrm{yr}$ (Wiltshire \& Manly 2004, Wiltshire et al. 2008) or hidden species diversity, i.e. the introduction of $P$. sulcata from warmer waters.

Hobson \& McQuoid (1997) found that the abundance of Paralia sulcata increased under low light conditions. This fact is supported by the present study, where growth of $P$. sulcata was negatively correlated with radiation and Secchi depth. Interestingly, annual mean Secchi depth has increased by $1 \mathrm{~m}$ in the North Sea over the last 30 yr (Wiltshire et al. 2008). However, no significant correlation with the Secchi depth and total algal densities in winter (January to March) has been found (Wiltshire et al. 2008), which could explain the increasing Secchi depth. The total algal density has increased in winter since the late 1980s in spite of decreasing phosphate and ammonia concentrations (Wiltshire et al. 2008). As a tychopelagic diatom species, $P$. sulcata could be indirectly influenced by the higher light availability in winter and summer due to an adaptation to higher light conditions. This could result in a change in the life cycle and ecological niche, which in turn could be a possible explanation for the new occurrence of this diatom in summer. Nevertheless, nothing is known about the exact life cycle of $P$. sulcata due to the slow growth rates of this diatom.

High nutrient concentrations in the water column in winter as a result of remineralisation processes are typical for temperate coastal waters (Wafar et al. 1983). This could be an explanation for the positive correlation between nutrient concentration and abundance of Paralia sulcata. Some studies have shown comparable positive correlations with abundance and higher nutrient concentrations, indicating that P. sulcata is common in nutrient-rich waters (Abrantes 1988, Zong 1997). The absence of the fast-growing spring bloom species in winter may support the occurrence of $P$. sulcata in the water column (Roelofs 1984). The significantly positive relationship between the abundance of $P$. sulcata and silicate concentrations indicate a high silicate demand of $P$. sulcata which could be attributed to its strongly silicified valves. The highest silicate concentrations in the present study were measured in winter and spring, after which the concentration decreased to half of those measured until autumn. In the spring bloom, silicate concentrations decrease rapidly due to the fast-growing spring bloom phytoplankton species which utilize the silicate very quickly (Wafar et al. 1983). 
The present study showed no strong correlations between salinity and abundance of Paralia sulcata, suggesting that this diatom can live in a wide range of salinities, as previously described in the literature (Zong 1997). In comparison, the distribution of P. sulcata in the phytoplankton in the British Columbia inlets appears to be strongly correlated to salinity, and P. sulcata abundance was negatively correlated with low salinity (Roelofs 1984).

The study site at the southern part of Vancouver Island is characterized by storm activity in the winter months, which could explain the higher abundance of Paralia sulcata in the phytoplankton as algal cells are transferred from the sediments into the plankton by wave activity (McQuoid \& Hobson 1998). Storm activity was not included in the present study. However, there are strong tidal mixing and storm activities at Helgoland Roads in summer and winter, which could explain the occurrence of P. sulcata, caused by the resuspension of chains into the water column.

The higher nutrient concentrations and lower temperature and light conditions in the water column during winter could be of advantage to the slow-growing Paralia sulcata. During spring, when water temperatures and light conditions are increasing, the fastgrowing spring bloom species may outcompete $P$. sulcata (Roelofs 1984), which could explain the absence or lower abundances of $P$. sulcata in summer.

\section{Long-term trends and ecological niche of Paralia sulcata}

This is the first time that niche parameters such as niche breadth and niche position were calculated for an alga found in a long-term data set, and a long-term trend can be shown for Paralia sulcata. This is also the first study to examine the ecological niche of $P$. sulcata in detail. Several studies with other organisms use the new method of OMI analysis of Dolédec et al. (2000). Heino \& Soininen (2006) used this method to characterize the stream diatom communities in 47 streams in northern Finland. The determinants of fish distribution in 97 lakes in southern and central Finland were also investigated with this method (Lappalainen \& Soininen 2006).

In the present study we investigated the ecological niche of Paralia sulcata over a time period of $38 \mathrm{yr}$. Changes from a more specialized niche in the 1980s to a more generalized niche in the late 1990s were exemplified by changes in the occurrence of P. sulcata over the last decade. Since 1996-1997, P. sulcata has occurred in the water column during summer at Helgoland Roads, resulting in a wider niche breadth and a more generalized ecological niche. These results indi- cate that the niche position of $P$. sulcata can change considerably within a time period of several decades.

The correlations between niche parameters of Paralia sulcata and environmental parameters grouped into the 4 clusters were inconsistent. The annual mean $\mathrm{SD}$ of the environmental parameters describes the variation of the parameters in an individual year. Significant correlations within the annual mean SD of individual environmental parameters and niche parameters of $P$. sulcata in the clusters indicate variation in the marine system at Helgoland Roads. If the marine system is variable (i.e. in terms of temperature, salinity, nitrite and Secchi depth), then the ecological niche of $P$. sulcata becomes more specialized. This means that the change in variability of an environmental parameter could lead to a change in the tolerance of this environmental parameter by $P$. sulcata, which leads to a more specialized niche. Therefore, the tolerated range of the individual parameter for P. sulcata could decrease when the range of the variability of this parameter converges to the upper or lower limit tolerated by $P$. sulcata.

Changes in the ecological niche of Paralia sulcata are mainly influenced by temperature and Secchi depth. This may be explained by the fact that regime shifts have occurred in the North Sea over the last 3 decades, which has resulted in a change in the fundamental niche of the North Sea. Weijerman et al. (2005) examined evidence for the regime shift in the North Sea using existing long-term data series on a wide range of physical and biological parameters from 1960 to 2002. Their results indicate that substantial regime shifts occurred in the North Sea in 1979 (salinity and changing weather conditions), 1988 (temperature and changing North Atlantic Oscillation Index) and 1998 (temperature). These regime shifts are most evident among biological parameters, e.g. the changes in the abundance of copepods (Reid et al. 2001, Weijerman et al. 2005, Martens \& van Beusekom 2008, Schlüter et al. 2008). The 1998 regime shift comprised an increase in storm activity and wind speed in the North Sea (Alexandersson et al. 2000, Weijerman et al. 2005, Wiltshire et al. 2008). Because of this storm-induced mixing of the water column, $P$. sulcata may increasingly be transferred from the benthos into the pelagial in summer at Helgoland Roads. Therefore, the realized ecological niche of $P$. sulcata could lead to a shift from a specialized to a more generalized niche.

Another possible explanation for the new occurrence of Paralia sulcata is a shift in the algal population that occurs in summer and winter at Helgoland Roads to include those species which are more adapted to warmer conditions. The next step of our research therefore will be to investigate genetic isolates from different times of the year. 


\section{CONCLUSIONS}

The present study found a change in the ecological niche of Paralia sulcata indicating a shift from a specialized (1980s) to a more generalized niche (since 1996) and a new occurrence of this diatom in summer over the last 10 yr. CCA extracted the most important factors influencing the abundance of $P$. sulcata in the water column: temperature, Secchi depth, light conditions and silicate, phosphate and nitrite concentrations. A seasonal pattern has shown that $P$. sulcata is a typical winter alga adapted to low light conditions under colder water temperatures but high concentrations of nutrients. However, the CCA does not show the shift in the occurrence of $P$. sulcata in the summer months since 1997 and cannot explain the niche displacement. Changing environmental conditions in the North Sea, such as increasing temperature and Secchi depth and decreasing phosphate and ammonia concentrations, may influence the occurrence of $P$. sulcata and result in the clear shift from a specialized to a generalized ecological niche. Another possibility is the introduction of $P$. sulcata strains from warmer waters which are adapted to the temperature conditions resulting from the recent warming trend of the North Sea. However, these factors alone do not explain the niche displacement of $P$. sulcata. Adaptation to the higher light regime and decreasing nutrient concentrations in the North Sea could be an advantage for the slow-growing $P$. sulcata in contrast to fast-growing phytoplankton species, as it may have resulted in a changing occurrence and a shift in the ecological niche of $P$. sulcata.

Acknowledgements. We thank the crews of RV 'Aade' and RV 'Ellenbogen' for their dedication to the long-term monitoring program and we acknowledge all those who measured temperature and nutrients and counted phytoplankton samples at Helgoland Roads. We are obliged to B. Geyer (GKSS, Gesthacht) for providing us with the radiation data. We are grateful to F. Hantzsche, K. Schoo, M. Löder, P. Brandt and N. Grüner for inspiring discussions. We thank 3 anonymous reviewers for reading the manuscript and providing helpful comments. This study is part of the Food Web project of the Alfred Wegener Institute in the PACES programme.

\section{LITERATURE CITED}

Abrantes F (1988) Diatom assemblages as upwelling indicators in surface sediments off Portugal. Mar Geol 85:15-39 Alexandersson H, Tuomenvirta H, Schmith T, Iden K (2000) Trends of storms in NW Europe derived from an updated pressure data set. Clim Res 14:71-73

Bartsch I, Tittley I (2004) The rocky intertidal biotopes of Helgoland: present and past. Helgol Mar Res 58:289-302

Bauerfeind E, Hickel W, Niermann U, Westernhagen HV (1990) Phytoplankton biomass and potential nutrient limitation of phytoplankton development in the Southeastern
North Sea in spring 1985 and 1986. Neth J Sea Res 25: 131-142

Begon M, Harper JL, Townsend CR (1996) Ecology: individuals, populations and community, 3rd edn. Blackwell Science, Oxford

Clarke KR, Warwick RM (2001) Change in marine communities: an approach to statistical analysis and interpretation. PRIMER-E, Plymouth

Crawford RM (1979) Filament formation in the diatom genera Melosira C.A. Agardh and Paralia Heiberg. Nova Hedwigia 64:121-133

Dolédec S, Chessel D, Gimaret-Carpentier C (2000) Niche separation in community analysis: a new method. Ecology 81:2914-2927

Franke HD, Gutow L (2004) Long-term changes in the macrozoobenthos around the rocky island of Helgoland (German Bight, North Sea). Helgol Mar Res 58:303-310

Franke HD, Bucholz F, Wiltshire KH (2004) Ecological longterm research at Helgoland (German Bight, North Sea): retrospect and prospect-an introduction. Helgol Mar Res 58:223-229

Gerdts G, Wichels A, Döpke H, Klings KW, Gunkel W, Schütt C (2004) 40-year long-term study of microbial parameters near Helgoland (German Bight, North Sea): historical view and future perspectives. Helgol Mar Res 58:230-242

Grasshoff K (1976) Methods of seawater analysis. Verlag Chemie, Weinheim, New York

Greve W, Reiners F, Nast J, Hoffmann S (2004) Helgoland Roads time-series meso- and macrozooplankton 1974 to 2004: lessons from 30 years of single spot high frequency sampling at the only off-shore island of the North Sea. Helgol Mar Res 58:274-288

Heino J, Soininen J (2005) Assembly rules and community models for unicellular organisms: patterns in diatoms of boreal streams. Freshw Biol 50:567-577

Heino J, Soininen J (2006) Regional occupancy in unicellular eukaryotes: a reflection of niche breadth, habitat availability or size-related dispersal capacity? Freshw Biol 51: 672-685

Hickel W (1998) Temporal variability of micro- and nanoplankton in the German Bight in relation to hydrographic structure and nutrient changes. ICES J Mar Sci 55: 600-609

Hobson LA, McQuoid MR (1997) Temporal variations among planktonic diatom assemblages in a turbulent environment of the southern Strait of Georgia, British Columbia, Canada. Mar Ecol Prog Ser 150:263-274

> Hoppenrath M (2004) A revised checklist of planktonic diatoms and dinoflagellates from Helgoland (North Sea, German Bight). Helgol Mar Res 58:243-251

Hutchinson GE (1957) Concluding remarks - Cold Spring Harbour Symposium. Quantitative Biol 22:415-427

> Kearney M (2006) Habitat, environment and niche: What are we modelling? Oikos 115:186-191

> Lappalainen J, Soininen J (2006) Latitudinal gradients in niche breadth and position - regional patterns in freshwater fish. Naturwissenschaften 93:246-250

Leps J, Smilauer P (2003) Multivariate analysis of ecological data using CANOCO. Cambridge University Press, Cambridge

> Lund JWG, Kipling C, Le Cren ED (1958) The inverted microscope method of estimating algal numbers and the statistical basis of estimations by counting. Hydrobiologia 11: 143-170

Martens P, van Beusekom JEE (2008) Zooplankton response to a warmer northern Wadden Sea. Helgol Mar Res 62:67-75 McGill BJ, Enquist BJ, Weiher E, Westoby M (2006) Rebuild- 
ing community ecology from functional traits. Trends Ecol Evol 21:178-185

McQuoid MR, Hobson LA (1998) Assessment of palaeoenvironmental conditions on Southern Vancouver Island, British Columbia, Canada, using the marine tychopankter Paralia sulcata. Diatom Res 13:311-321

McQuoid MR, Nordberg K (2003a) Environmental influence on the diatom and silicoflagellate assemblages in Koljö Fjord (Sweden) over the last two centuries. Estuaries 26: 927-937

McQuoid MR, Nordberg K (2003b) The diatom Paralia sulcata as an environmental indicator species in coastal sediments. Estuar Coast Shelf Sci 56:339-354

Medlin LK, Kooistra WHCF, Gersonde R, Sims PA, Wellbrock $\mathrm{U}$ (1997) Is the origin of the diatoms related to the end-Permian mass extinction? Nova Hedwigia 65:1-11

R Development Core Team (2007) R: a language and environment for statistical computing. R Foundation for Statistical Computing, Vienna. www.R-project.org

Raabe T, Wiltshire KH (2009) Quality control and analyses of the long-term nutrient data from Helgoland Roads, North Sea. J Sea Res 61: 3-16

Reid PC, de Fatima Borges M, Svendsen E (2001) A regime shift in the North Sea circa 1988 linked to changes in the North Sea horse mackerel fishery. Fish Res 50:163-171

Roelofs AK (1984) Distributional patterns and variation of valve diameter of Paralia sulcata in surface sediments of Southern British Columbia Inlets. Estuar Coast Shelf Sci 18:165-176

Schlüter MH, Merico A, Wiltshire KH, Greve W, von Storch H (2008) A statistical analysis of climate variability and ecosystem response in the German Bight. Ocean Dyn 58:
169-186

ter Braak CJE, Verdonschot PEM (1995) Canonical correspondence analysis and related multivariate methods in aquatic ecology. Aquat Sci 57:255-289

Tsiftsis S, Tsiripidis I, Karagiannakidou V, Alifragis D (2008) Niche analysis and conservation of the orchids of east Macedonia (NE Greece). Acta Oecol 33:27-35

Wafar MVM, Le Corre P, Birrien JL (1983) Nutrients and primary production in permanently well-mixed temperate coastal waters. Estuar Coast Shelf Sci 17:431-446

Weijerman M, Lindeboom H, Zuur AF (2005) Regime shifts in marine ecosystems of the North Sea and Wadden Sea. Mar Ecol Prog Ser 298:21-39

Wiltshire KH, Dürselen CD (2004) Revision and quality analyses of the Helgoland Reede long-term phytoplankton data archive. Helgol Mar Res 58:252-268

Wiltshire KH, Manly BFJ (2004) The warming trend at Helgoland Roads, North Sea: phytoplankton response. Helgol Mar Res 58:269-273

Wiltshire KH, Malzahn AM, Wirtz K, Greve W and others (2008) Resilience of North Sea phytoplankton spring bloom dynamics: an analysis of long-term data at Helgoland Roads. Limnol Oceanogr 53:1294-1302

Wiltshire KH, Bartsch I, Boersma M, Franke HD and others (in press) Helgoland Roads, North Sea: 45 years of change. Estuar Coast Shelf Sci

Wirtz K, Wiltshire KH (2005) Long-term shifts in marine ecosystem functioning detected by inverse modeling of the Helgoland Roads time-series. J Mar Sys 56:262-282

Zong Y (1997) Implications of Paralia sulcata abundance in Scottish isolation basins. Diatom Res 12:125-150 
Appendix 1

Table A1. Conditional effects of the environmental parameters of the canonical correspondence redundancy analyses for the years 1968 to 2005 . Significant values are indicated by asterisks: ${ }^{*} p<0.05 ;{ }^{* *} p<0.01 ; n s=$ not significant

\begin{tabular}{|c|c|c|c|c|c|c|c|c|c|c|}
\hline Year & Temp & Delta T & Secchi & Sal & Rad & $\mathrm{PO}_{4}$ & $\mathrm{NO}_{2}$ & $\mathrm{NO}_{3}$ & $\mathrm{NH}_{4}$ & $\mathrm{SiO}_{4}$ \\
\hline 1968 & * & * & * & ns & $* *$ & * & * & ns & $* *$ & * \\
\hline 1969 & $* *$ & $*$ & ns & $* *$ & ns & ns & $* *$ & ns & ns & $* *$ \\
\hline 1970 & ns & ns & $*$ & ${ }^{* *}$ & ${ }^{*}$ & $*$ & $*$ & ns & ${ }^{* *}$ & ${ }^{* *}$ \\
\hline 1971 & $* *$ & $*$ & ns & ns & $* *$ & ns & $* *$ & ns & ns & ns \\
\hline 1972 & $* *$ & ns & $*$ & $* *$ & $* *$ & $*$ & ns & ns & $*$ & $* *$ \\
\hline 1973 & $* *$ & ns & ns & $*$ & $* *$ & ns & ns & $* *$ & ns & ns \\
\hline 1974 & ns & $* *$ & $* *$ & ns & $* *$ & $* *$ & ns & $* *$ & ns & $*$ \\
\hline 1975 & $* *$ & $*$ & $* *$ & $* *$ & $*$ & $* *$ & ** & ns & ** & $* *$ \\
\hline 1976 & ns & $*$ & $* *$ & $*$ & ns & ns & ** & $* *$ & ns & $*$ \\
\hline 1977 & ns & ns & ** & ns & ns & $* *$ & $*$ & ns & $* *$ & $* *$ \\
\hline 1978 & ns & ns & $* *$ & ns & ns & $*$ & $*$ & $* *$ & $\mathrm{~ns}$ & $* *$ \\
\hline 1979 & ${ }^{* *}$ & ns & ${ }^{* *}$ & ns & ${ }^{* *}$ & ${ }^{* *}$ & ns & ns & ns & ${ }^{* *}$ \\
\hline 1980 & ns & ns & ns & $* *$ & $*$ & ns & ns & $* *$ & ns & ns \\
\hline 1981 & ns & ns & $* *$ & $*$ & * & $* *$ & $*$ & $* *$ & ns & ${ }^{* *}$ \\
\hline 1982 & ns & ns & $* *$ & $*$ & $* *$ & ns & ns & ns & $\mathrm{ns}$ & $*$ \\
\hline 1983 & ${ }^{* *}$ & ns & ${ }^{* *}$ & ns & ns & ${ }^{* *}$ & ${ }^{* *}$ & ${ }^{*}$ & ns & ${ }^{*}$ \\
\hline 1984 & $* *$ & ns & $*$ & ns & $* *$ & ns & ns & $*$ & ns & ns \\
\hline 1985 & ns & ns & ${ }^{* *}$ & ns & ns & $* *$ & $*$ & $* *$ & ns & ns \\
\hline 1986 & ns & ${ }^{* *}$ & ${ }^{* *}$ & ${ }^{* *}$ & ${ }^{* *}$ & ns & ns & ${ }^{* *}$ & ${ }^{*}$ & ns \\
\hline 1987 & $* *$ & $* *$ & $* *$ & ns & ns & $* *$ & $*$ & ns & $* *$ & ns \\
\hline 1988 & $* *$ & $*$ & ns & ns & ns & $*$ & ${ }^{* *}$ & $*$ & $*$ & ${ }^{* *}$ \\
\hline 1989 & $* *$ & $*$ & ns & $*$ & $* *$ & ns & ns & $\mathrm{ns}$ & $*$ & $* *$ \\
\hline 1990 & $* *$ & ns & $*$ & ns & $* *$ & ns & $* *$ & ${ }^{* *}$ & ${ }^{* *}$ & ns \\
\hline 1991 & ns & $*$ & * & $*$ & ns & $*$ & ${ }^{* *}$ & $* *$ & ns & $* *$ \\
\hline 1992 & $* *$ & $*$ & $*$ & $* *$ & $* *$ & ns & ns & $\mathrm{ns}$ & $* *$ & $* *$ \\
\hline 1993 & ${ }^{* *}$ & ns & ${ }^{* *}$ & ${ }^{* *}$ & ${ }^{*}$ & ns & ${ }^{* *}$ & ns & ns & ${ }^{* *}$ \\
\hline 1994 & ns & ns & ns & ns & $* *$ & ns & ns & ns & ns & ns \\
\hline 1995 & $* *$ & ns & $*$ & $* *$ & $* *$ & $* *$ & $* *$ & $\mathrm{~ns}$ & ns & $* *$ \\
\hline 1996 & ${ }^{* *}$ & ns & ns & ns & ns & ns & ns & ns & ${ }^{*}$ & ns \\
\hline 1997 & ns & $* *$ & $* *$ & $* *$ & $*$ & ns & $* *$ & $* *$ & $*$ & $* *$ \\
\hline 1998 & ns & ns & ns & ns & ${ }^{* *}$ & ns & ns & ns & ns & ns \\
\hline 1999 & ns & ns & ns & ns & ${ }^{* *}$ & ns & ns & ns & ns & ns \\
\hline 2000 & ns & ns & ns & ns & ns & ${ }^{* *}$ & ns & $*$ & ns & ns \\
\hline 2001 & ns & ns & $*$ & ns & ns & ns & ns & $\mathrm{ns}$ & ns & ns \\
\hline 2002 & ${ }^{* *}$ & ns & ${ }^{* *}$ & ns & ${ }^{* *}$ & $*$ & ${ }^{* *}$ & ns & ${ }^{*}$ & $*$ \\
\hline 2003 & ns & ns & ns & ns & ${ }^{* *}$ & ns & ns & ns & ns & ns \\
\hline 2004 & ns & ns & ns & ns & $* *$ & ns & ns & ns & ns & ns \\
\hline 2005 & ${ }^{* *}$ & ns & $*$ & $*$ & ${ }^{* *}$ & ns & ns & ns & $* *$ & ns \\
\hline 1968-2005 & $* *$ & $* *$ & $* *$ & $* *$ & $* *$ & $* *$ & $* *$ & $*$ & $* *$ & $*$ \\
\hline
\end{tabular}

Editorial responsibility: Max Tilzer, Konstanz, Germany
Submitted: October 14, 2008; Accepted: September 11, 2009 Proofs received from author(s): October 22, 2009 